\title{
ه Paris Agreement climate proposals need a boost to keep warming well below $2^{\circ} \mathrm{C}$
}

Joeri Rogelj ${ }^{1,2}$, Michel den Elzen ${ }^{3}$, Niklas Höhne ${ }^{4,5}$, Taryn Fransen ${ }^{6}$, Hanna Fekete ${ }^{4}$, Harald Winkler ${ }^{7}$, Roberto Schaeffer ${ }^{8}$, Fu Sha ${ }^{9}$, Keywan Riahi ${ }^{1,10} \&$ Malte Meinshausen ${ }^{11,12}$

The Paris climate agreement aims at holding global warming to well below 2 degrees Celsius and to "pursue efforts" to limit it to 1.5 degrees Celsius. To accomplish this, countries have submitted Intended Nationally Determined Contributions (INDCs) outlining their post-2020 climate action. Here we assess the effect of current INDCs on reducing aggregate greenhouse gas emissions, its implications for achieving the temperature objective of the Paris climate agreement, and potential options for overachievement. The INDCs collectively lower greenhouse gas emissions compared to where current policies stand, but still imply a median warming of 2.6-3.1 degrees Celsius by 2100. More can be achieved, because the agreement stipulates that targets for reducing greenhouse gas emissions are strengthened over time, both in ambition and scope. Substantial enhancement or over-delivery on current INDCs by additional national, sub-national and non-state actions is required to maintain a reasonable chance of meeting the target of keeping warming well below 2 degrees Celsius.

I n December 2015, the Paris Agreement ${ }^{1}$ - a new global agreement to combat climate change-was adopted under the United Nations $\perp$ Framework Convention on Climate Change (UNFCCC). In preparation of this agreement, countries submitted national plans that spell out their intentions for addressing the climate change challenge after $2020^{2}$. These Intended Nationally Determined Contributions (INDCs) address a range of issues, which can relate to avoiding, adapting or coping with climate change, among other things. Nevertheless, targets and actions for reducing greenhouse gas (GHG) emissions are core components. At this point, the INDCs are not final and can be modified up until the time the Paris Agreement is ratified. However, for now they represent our best understanding of the climate actions countries intend to pursue after 2020.

The overarching climate goal of the Paris Agreement is to hold "the increase in the global average temperature to well below $2^{\circ} \mathrm{C}$ above preindustrial levels and to pursue efforts to limit the temperature increase to $1.5^{\circ} \mathrm{C}$ above pre-industrial levels" ${ }^{\prime}$. This climate goal represents the level of climate change that governments agree would prevent dangerous interference with the climate system, while ensuring sustainable food production and economic development ${ }^{3,4}$, and is the result of international discussions over multiple decades ${ }^{5}$. Limiting warming to any level implies that the total amount of carbon dioxide $\left(\mathrm{CO}_{2}\right)$ that can ever be emitted into the atmosphere is finite ${ }^{6}$. From a geophysical perspective, global $\mathrm{CO}_{2}$ emissions thus need to become net zero ${ }^{7,8}$. About two thirds of the available budget for keeping warming to below $2{ }^{\circ} \mathrm{C}$ have already been emitted ${ }^{9-11}$, and increasing trends in $\mathrm{CO}_{2}$ emissions ${ }^{12}$ indicate that global emissions urgently need to start to decline so as to not foreclose the possibility of holding warming to well below $2{ }^{\circ} \mathrm{C}$ (refs 13, 14). The window for limiting warming to below $1.5^{\circ} \mathrm{C}$ with high probability and without temporarily exceeding that level already seems to have closed ${ }^{15}$. The Paris Agreement implicitly acknowledges these insights and aims to reach a global peak in GHG emissions as soon as possible together with achieving "a balance" between anthropogenic emissions and removals of GHGs in the second half of this century. Both targets are in principle consistent with the temperature objective of the Agreement ${ }^{16,17}$, but beg the broader question of whether current INDCs are already putting the world on a path towards achieving them.

Besides the climate question, the first round of INDCs also raises many other issues. These include whether efforts are distributed equitably among countries; how much adaptation may be required given the current level of mitigation ambition; how 'intended' national proposals will be implemented; how they will be financed; and the extent to which the INDCs contribute to the achievement of other goals of the UNFCCC by building on institutions that can support adaptation to climate change, technology advancement, development path transformation, sustainable development and enhanced awareness. Although these issues are important for many countries, they fall outside the scope of this analysis.

In this Perspective, we assess the implications of the current INDCs for GHG emissions, including the main factors and uncertainties that influence the levels of GHG emissions in 2030-the latest year covered by the vast majority of INDCs-and we explore the consistency of these reductions with the objective of the Paris Agreement (to keep warming well below $2{ }^{\circ} \mathrm{C}$ and pursue efforts towards $1.5^{\circ} \mathrm{C}$ ). This work updates and expands work undertaken in the framework of the 2015 United Nations Environment Programme (UNEP) Emissions Gap Report ${ }^{18}$ - an authoritative annual assessment that has tracked climate policy action over the past six years, and provides a synthesis of a wide range of INDC modelling studies ${ }^{19-29}$ that are available in the public domain. The number of INDCs considered by the studies that we assess here ranges from the 118 INDCs submitted by 1 October 2015 to the 160 INDCs submitted by 12 December 2015 (Supplementary Tables 1 and 2). These 118 to 160 INDCs cover emissions from 145 to 187 out of 195 Parties to the UNFCCC, which in turn were responsible for roughly $88 \%$ to more than $96 \%$ of global GHG emissions in $2012^{30}$. We also look at projections of global-mean temperature increase over the twenty-first century that would be consistent with the INDCs, and at post-2030 implications for limiting warming to no more than $2{ }^{\circ} \mathrm{C}$. Finally, we discuss options to

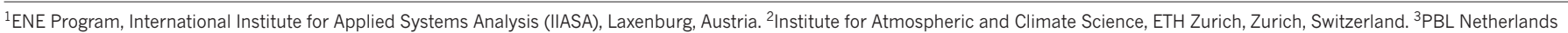
Environmental Assessment Agency, Bilthoven, The Netherlands. ${ }^{4}$ NewClimate Institute, Cologne, Germany. ${ }^{5}$ Environmental Systems Analysis Group, Wageningen University, Wageningen, The Netherlands. ${ }^{6}$ World Resources Institute, Washington DC, USA. ${ }^{7}$ University of Cape Town, Cape Town, South Africa. ${ }^{8}$ Universidade Federal do Rio de Janeiro (COPPE/UFRJ), Rio de Janeiro, Brazil.

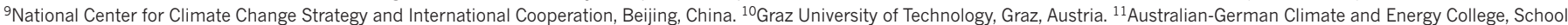
of Earth Sciences, The University of Melbourne, Melbourne, Victoria, Australia. ${ }^{12}$ PRIMAP Group, Potsdam Institute for Climate Impact Research (PIK), Potsdam, Germany. 


\section{BOXI Scenario definitions}

Scenarios represent alternative images of the future, or "[stories] about what happened in the future" 76 . They are neither predictions nor forecasts ${ }^{77}$, but tools to understand how the future might unfold under a consistent set of assumptions. In this analysis, we use four types of scenarios, drawn from a wide variety of sources.

No-policy baseline scenarios. These are emissions projections that assume that no new climate policies have been put into place from 2005 onwards. We select these scenarios from the IPCC AR5 Scenario Database ${ }^{16}$, which is hosted at the International Institute for Applied Systems Analysis (IIASA, https://tntcat.iiasa.ac.at/AR5DB/). By design, these no-policy baseline scenarios exclude climate policies, but may include other policies that can influence emissions and are implemented for other reasons, such as energy efficiency or energy security policies.

Current-policy scenarios. These consider the most recent estimates of global emissions and take into account implemented national policies. This is different from the INDC scenarios (described below), which reflect international pledges and intended policies. Here, we draw these scenarios from three global analyses ${ }^{19,29,78}$.

INDC scenarios. These project how global GHG emissions evolve under a successful implementation of the INDCs. These projections are based on ten global INDC analyses ${ }^{19-29}$ (Supplementary Table 2 provides an overview), in which calculations can be based on official estimates from countries or on documents submitted to the UNFCCC (such as national GHG inventories, national communications, biennial reports or biennial update reports). INDCs were submitted before the Paris summit; under the Paris Agreement, future mitigation contributions will be referred to as NDCs, without the 'intended'.

$2^{\circ} \mathrm{C}$ scenarios. These are idealized global scenarios limiting warming to well below $2^{\circ} \mathrm{C}$, keeping open the option of strengthening the global temperature target to $1.5^{\circ} \mathrm{C}$. These scenarios are based on a subset of scenarios from the IPCC AR5 Scenario Database (Supplementary Table 3) that meet the following criteria: they have a greater than $66 \%$ probability of keeping warming to below $2^{\circ} \mathrm{C}$ by 2100 (this probability does not drop below $60 \%$ at any point during the entire twenty-first century); until 2020, they assume that actions that were pledged earlier under the UNFCCC Cancun Agreement are fully implemented; and, after 2020, they distribute emission reductions across regions, gases and sectors so that the total discounted costs of the necessary global reductions are minimized. These scenarios distribute emissions reductions among regions in the most cost-optimal way, and are often referred to as least-cost or cost-optimal trajectories. However, this does not imply that the actual costs to achieve this cannot be distributed differently, for example, on the basis of other equity principles ${ }^{79}$. A separate set of scenarios is used to examine the post-2030 implications of current INDCs for $2^{\circ} \mathrm{C}$ (Supplementary Table 4).

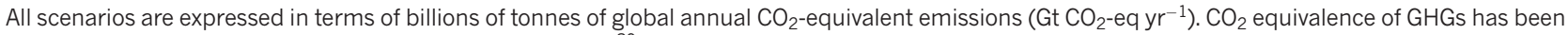
calculated by means of 100 -year global warming potentials ${ }^{80}$.

further reduce global GHG emissions in 2030 from their INDC levels towards levels that are more consistent with a long-term global pathway that limits warming to well below $2^{\circ} \mathrm{C}$.

We use four scenario groups to frame the implications of the INDCs for global GHG emissions in 2030: no-policy baseline scenarios, current-policy scenarios, INDC scenarios and least-cost $2{ }^{\circ} \mathrm{C}$ scenarios. Their definitions and descriptions are provided in Box 1.

\section{Aggregate emissions impact of INDCs}

A first, obvious question to ask is what the submitted INDCs deliver in terms of GHG emissions out to 2030. What sounds like simple arithmetic turns out to be a more complicated accounting exercise with an array of possible outcomes. Some countries provide a range instead of a single number of emissions reductions in their INDCs. Many INDCs lack necessary details, such as clarity on sectors and gases covered, details on the impact of listed mitigation actions, different metrics to aggregate gases, details on base year or reference values from which reductions or improvements would be measured, or accounting practices related to land use and the use of specific market mechanisms ${ }^{31}$. This murkiness complicates a precise estimate of their impact on emissions. Finally, some of the actions listed in INDCs are, either implicitly or explicitly, conditional on other factors, such as the availability of financial or technological support. All these factors can be interpreted differently and influence the range of possible outcomes. In our assessment, we distinguish between a conditional and an unconditional INDC scenario, with associated uncertainties. Interestingly, the Paris Agreement does not adopt such distinction, and instead defers any discussion on features of countries' contributions to further negotiations.

Unconditionally, the INDCs are expected to result in global GHG emissions of about 55 (52-58; 10th-90th percentile range over all studies unless otherwise stated) billion metric tonnes of annual $\mathrm{CO}_{2}$ equivalent emissions $\left(\mathrm{Gt} \mathrm{CO}_{2}\right.$-eq $\mathrm{yr}^{-1}$; Box 1, Fig. 1, Supplementary Text $1)$ in 2030. This is a reduction of around $9(7-13) \mathrm{Gt} \mathrm{CO}_{2}$-eq $\mathrm{yr}^{-1}$ by 2030 relative to the median no-policy baseline scenario estimate and of

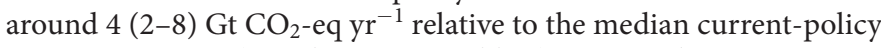
scenario estimate (Supplementary Table 5). Putting this into context, global GHG emissions in 2010 are estimated at about $48 \mathrm{Gt} \mathrm{CO}_{2}$-eq $\mathrm{yr}^{-1}$ (46-50 $\mathrm{Gt} \mathrm{CO}_{2}$-eq $\mathrm{yr}^{-1}$; range across studies, Supplementary Table 2), and our median no-policy baseline estimate reaches about $65 \mathrm{Gt} \mathrm{CO}_{2}$-eq $\mathrm{yr}^{-1}$ by 2030 .

A number of countries place conditions-for example, the provision of international finance-on all or part of their INDC. Some countries (such as Mexico, Indonesia and Morocco) included a range of reduction targets in their INDC and attach conditions to the implementation of the more ambitious end. Other countries indicate that their entire INDC is conditional. Of the INDCs submitted by 12 December 2015, roughly $45 \%$ came with both conditional and unconditional components; about a third was conditional only; and the remainder did not specify conditions ${ }^{32}$. When we assume in our evaluation that all conditions are met and conditional INDCs are fully implemented, estimated global

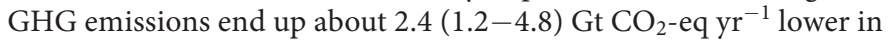
2030 compared to the unconditional INDC scenario case (full range across six available estimates, Supplementary Text 1, Supplementary Table 5).

Comparing the INDC scenario (what countries propose as their contribution to the international agreement) to the current-policy scenario (what countries implement domestically) provides lessons on the extent to which additional national policies are necessary to achieve the intended 2030 emissions reductions ${ }^{18}$. Projected emissions under current policies that match (or are lower than) those under the INDC can result either from a proactive and coordinated domestic policy response consistent with the INDC or from an INDC that is explicitly designed not to require further policy effort. Likewise, projected emissions under current policy that exceed those under the INDC can result from a relatively ambitious INDC, from a lack of domestic climate policy, or a combination thereof. Therefore, this comparison alone cannot adequately reflect the overall level of ambition.

For a number of countries (such as Russia and Ukraine), the INDC targets suggest that emission levels above their estimated no-policy baseline or current-policy scenario will be reached. These countries are thus expected to overachieve their INDC targets by default. Under the rules of the Kyoto Protocol, over-delivery on a target would have generated surplus emission allowances by the quantity the target level is overachieved. These allowances can then be traded with other countries, who apply them to achieve their own GHG reduction target. Such a system could also be developed under the Paris Agreement, which allows for 


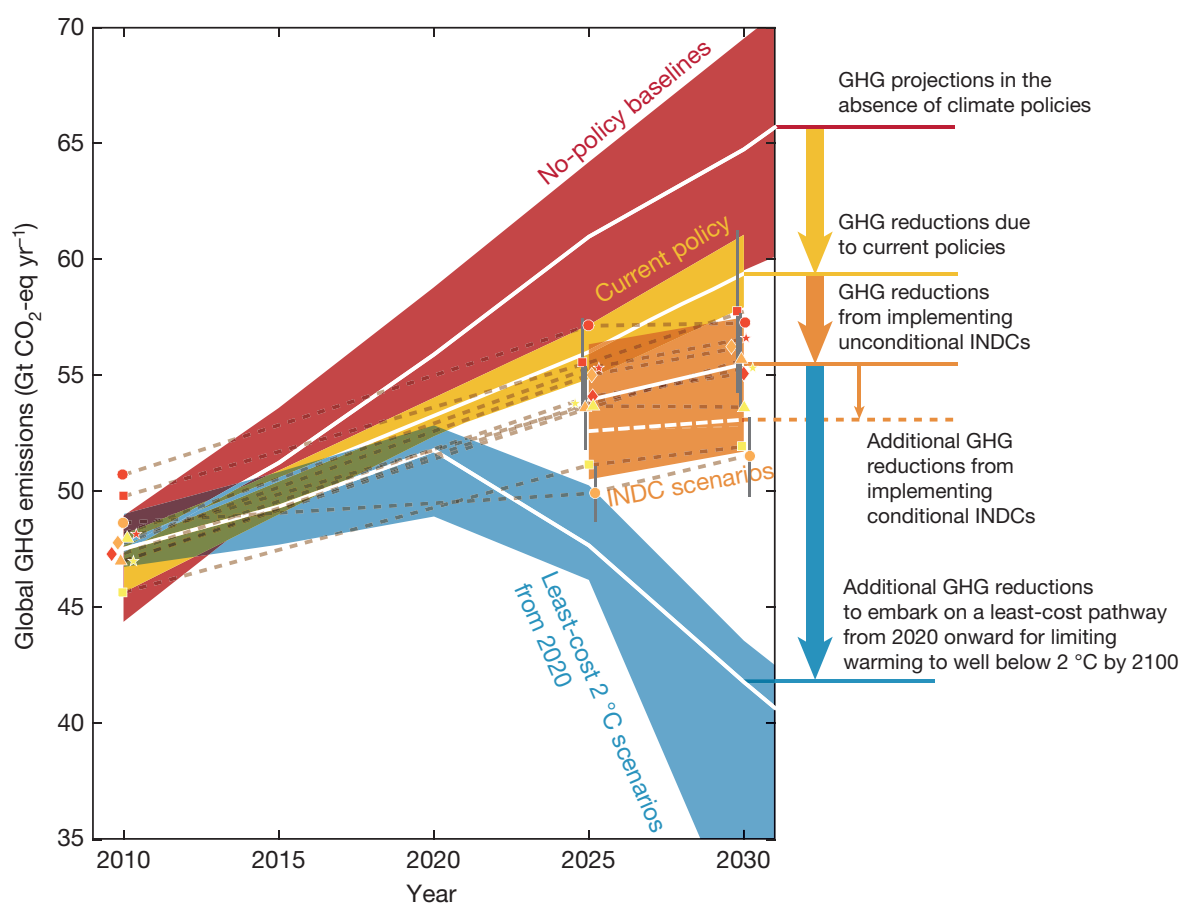

Assessed modelling studies

- Climate Action Tracker

- PBL, The Netherlands

IEA (eomplemented)

- LSE, UK

$\triangle$ Univ. of Melbourne, Australia

DEA, Denmark
Figure 1 | Global greenhouse gas emissions as implied by INDCs compared to no-policy baseline, current-policy and $2^{\circ} \mathrm{C}$ scenarios.

White lines show the median of each range. The white dashed line shows the median estimate of what the INDCs would deliver if all conditions are met. The 20th-80th-percentile ranges are shown for the no-policy baseline and $2{ }^{\circ} \mathrm{C}$ scenarios. For current-policy and INDC scenarios, the minimum-maximum and 10th-90th-percentile range across all assessed studies are given, respectively. Symbols represent single studies, and are offset slightly to increase readability. Dashed brown lines connect data points for each study. Scenarios are described in Box 1. the voluntary use of "internationally transferred mitigation outcomes". However, the extent to which such a mechanism will ultimately be developed and used remains unclear, because it will require features, information and accounting of contributions to become much more precise than they are now. Different modelling teams treat these surpluses in different ways, which adds an uncertainty of about $1 \mathrm{Gt} \mathrm{CO}_{2}-\mathrm{eq}^{-1}$ to the estimates presented here.

\section{Confounding factors}

The literature synthesized in this assessment reveals a wide range of estimates of future emissions under nominally similar scenarios (see small symbols in Fig. 1). These differences can stem from a number of factors, including modelling methods, input data and assumptions regarding country intent. Our review identifies four key factors that contribute to the discrepancies and differences between the various 2030 emissions estimates.

\section{Incomplete coverage}

Several global and national sectors as well as countries are not covered by INDCs. Often, emissions estimates for sectors that are not included under INDCs range widely. This is the case for, for example, global emissions from international aviation (despite an industry pledge outside the UNFCCC ${ }^{33}$ ) and maritime transport, or the national non- $\mathrm{CO}_{2}$ GHG emissions from China. Subtracting national sectors that are not covered, INDCs cover at least 8 percentage points less of global emissions than the $96 \%$ indicated earlier (Supplementary Text 2). Under the Paris Agreement, developing countries are encouraged to move over time to economy-wide targets, so that future analyses should become more comprehensive. Countries that are not a UNFCCC Party or have not yet put forward an INDC are also studied in less depth, but represent only a diminishing amount of global emissions (about 1\%-2\%). Finally, studies themselves make specific choices about which INDCs to cover or focus on, which in turn influence projected emissions.

\section{Uncertain projections}

GHG emission projections of countries that have submitted INDCs are uncertain, particularly if targets are not unambiguously translatable in absolute emission reductions. Most INDCs do define straight-forward, absolute GHG emission targets (in units of $\mathrm{CO}_{2}$-eq in a given year or period), or targets that can be relatively easily translated into absolute levels (for example, a reduction from a fixed historical base year), but this is not always the case. About 75 INDCs are defined relative to hypothetical 'business-as-usual' or reference scenarios in the absence of climate pol$i_{c y}{ }^{32}$. In some cases governments do not define their reference scenario, and in other cases official projections differ substantially from those from international and national modelling teams. Overall, these uncertainties should become smaller, because the Paris decisions request countries to ensure some methodological consistency of future submissions. Another complicating factor is that several countries put forward targets that do not directly specify emissions (such as a renewable energy target) or targets on emissions intensity (for instance, improvements of the ratio of carbon emissions, $\mathrm{CO}_{2}$, to economic output, GDP). If the expected GDP growth rate is not provided, additional assumptions are required to quantify the implied absolute level of GHG emissions and these assumptions differ across modelling groups. For example, the estimated emissions for China for 2030 under its INDC range from $12.8 \mathrm{Gt} \mathrm{CO}_{2}$-eq yr${ }^{-1}$ to $15.0 \mathrm{Gt} \mathrm{CO}_{2}$-eq $\mathrm{yr}^{-1}$ in different studies ${ }^{22,34,35}$. At least seven other INDCs, including India's, are subject to the same kind of uncertainties (Supplementary Table 1). Finally, many countries (about 30, amounting to approximately $6 \%$ of global emissions) include mere qualitative descriptions of mitigation actions in their INDCs, which complicate a precise quantification.

\section{Land-use-related emissions}

Various approaches exist to account for emissions from land use, landuse change and forestry, and countries can use an accounting approach of their choice in their INDCs. Examples of possible approaches are 
Table 1 | Estimates of global temperature rise for INDC and other scenarios categories

\begin{tabular}{|c|c|c|c|}
\hline \multirow[t]{2}{*}{ Scenario } & \multicolumn{3}{|c|}{ Global-mean temperature rise by $2100\left(\right.$ in ${ }^{\circ} \mathrm{C}$ ) that is not exceeded with the given probability } \\
\hline & $50 \%$ & $66 \%$ & $90 \%$ \\
\hline No-policy baseline & $4.1(3.5-4.5)[3.1-4.8]$ & $4.5(3.9-5.1)[3.4-5.4]$ & $5.6(4.8-6.3)[4.2-6.8]$ \\
\hline Current policy & $3.2(3.1-3.4)[2.7-3.8]$ & $3.6(3.4-3.7)[2.9-4.1]$ & $4.4(4.2-4.6)[3.6-5.2]$ \\
\hline INDC (unconditional) & $2.9(2.6-3.1)[2.2-3.5]$ & $3.2(2.9-3.4)[2.4-3.8]$ & $3.9(3.5-4.2)[2.8-4.7]$ \\
\hline INDC (conditional) & $2.7(2.5-2.9)[2.1-3.2]$ & $3.0(2.7-3.1)[2.2-3.6]$ & $3.7(3.3-3.9)[2.6-4.4]$ \\
\hline
\end{tabular}

to include land-use-related $\mathrm{CO}_{2}$ emissions and removals as part of the national total, much like any other sector (an approach favoured by, for example, Brazil and USA), or to apply accounting rules similar to the ones under the Kyoto Protocol (which are favoured by, for example, the European Union and New Zealand, and possibly by Russia). These accounting rules can have a substantial effect on the emissions of individual countries in 2025 and $2030^{36}$ and are associated with substantial uncertainties. Although some INDCs explicitly exclude land-use-related emissions from their targets, many INDCs that include land use in their targets do not specify an accounting approach.

\section{Historical emissions and metrics}

Historical emission estimates come with their associated uncertainties. For example, recently, global 2010 GHG emissions have been estimated at $49 \mathrm{Gt} \mathrm{CO}_{2}$-eq yr ${ }^{-1}\left( \pm 4.5 \mathrm{Gt} \mathrm{CO}_{2} \text {-eq } \mathrm{yr}^{-1}, 90 \% \text { confidence interval }\right)^{37}$. Model teams apply their own estimate of historical emissions in their INDC analyses (Fig. 1), and both INDCs and analysts use varying metrics to translate GHG emissions into units of $\mathrm{CO}_{2}$-equivalence. Even if these discrepancies can be harmonized ${ }^{38}$ or corrected for, their variation increases the uncertainty surrounding INDC estimates.

\section{Optimal $2^{\circ} \mathrm{C}$ pathways}

Having quantified the GHG implications of the INDCs by 2030, the question remains whether these levels are consistent with the Paris Agreement's aim of holding warming to well below $2{ }^{\circ} \mathrm{C}$. As indicated earlier, limiting warming to any level requires net $\mathrm{CO}_{2}$ emissions to become zero at some point in time and, given the small remaining carbon budget, this moment is estimated to be before the end of this century for a $2^{\circ} \mathrm{C}$ limit ${ }^{11,17}$. The Paris Agreement's aim of reaching net-zero GHG emissions in the second half of the century goes even further. For some non- $\mathrm{CO}_{2}$ emissions, in particular those related to agriculture, only limited mitigation options have been identified ${ }^{39}$. Therefore, net-zero $\mathrm{CO}_{2}$ emissions are always achieved before achieving net-zero GHG emissions. Integrated energy-economy models are used extensively to model pathways that can achieve this feat at global least $\operatorname{cost}^{16}$. Here, we use the Scenario Database that accompanied the Fifth Assessment Report (AR5) of the Intergovernmental Panel on Climate Chang (IPCC) to explore such cost-optimal $2^{\circ} \mathrm{C}$ pathways from 2020 onward (Box 1).

Comparing these cost-optimal $2{ }^{\circ} \mathrm{C}$ scenarios to the INDC projections shows a large discrepancy (Fig. 1). The median cost-optimal path towards keeping warming to below $2^{\circ} \mathrm{C}$ (starting reductions in 2020) and the emissions currently implied by the unconditional INDCs differ by about 14 (10-16) Gt $\mathrm{CO}_{2}$-eq $\mathrm{yr}^{-1}$ in 2030. Even if the conditions that are linked to some INDCs are met (see earlier), this difference remains of the order of $11 \mathrm{Gt} \mathrm{CO}_{2}$-eq $\mathrm{yr}^{-1}$. The high end of this range $\left(16 \mathrm{Gt} \mathrm{CO}_{2}\right.$-eq yr $\left.{ }^{-1}\right)$ corresponds roughly to the 2010 emissions of China and USA combined; the lower end (about $10.5 \mathrm{Gt} \mathrm{CO}_{2}$-eq $\mathrm{yr}^{-1}$ ) to the sum of the emissions of Brazil, the European Union, India and Russia. Thus, the INDCs clearly do not put the world on a least-cost path towards limiting warming to well below $2^{\circ} \mathrm{C}$.

Any global emission scenario reflects an idealized representation of the world. This is not different for the cost-optimal $2^{\circ} \mathrm{C}$ scenarios that were used above as a reference. The strength of such cost-optimal scenarios lies in the fact that they provide an assessment of the potential for emission reductions in a world that collaborates globally towards limiting climate change and attempts to do this at lowest overall cost. Other scenarios in the literature model other, more imperfect futures, for example, those in which climate action is delayed by a few decades ${ }^{13,14,40,41}$, in which countries and regions are not collaborating from the beginning ${ }^{42}$, or in which the strength of local institutions affects the willingness to invest ${ }^{43}$. Such scenarios help us to explore the post-2030 implications of the current INDCs.

\section{Post-2030 implications of INDCs}

A large share of the potential warming until 2100 is determined not just by the INDCs until 2025 or 2030 , but also by what happens afterwards. Several conceptual approaches can be followed to extend INDCs into the future, which basically assume that climate action stalls, continues or accelerates. Stalling action is often modelled by assuming that emissions return to a no-climate-policy trajectory after 2030; continuing action by assuming that the level of post-2030 action is similar to pre-2030 action on the basis of a metric of choice (for example, extrapolating INDC trends in terms of carbon-price development or emissions intensity of the economy); and accelerating action by post- 2030 action that goes beyond such a level. Because of the path-dependence and inertia of the global energy system $^{44,45}$, the INDCs have a critical role in preparing what can come after 2030 .

Each of the above-mentioned approaches leads to different global temperature outcomes, even when starting from the same INDC assessment for 2030. It is therefore essential to spell out post-2030 assumptions to understand global temperature projections for the twenty-first century based on the INDCs. As a conservative interpretation of the Paris Agreement, we here assume that climate action continues after 2030 at a level of ambition that is similar to that of the INDCs (Supplementary Text 3). The assumption that climate action will continue or accelerate over time is supported by the Agreement's requirement that the successive nationally determined contribution of each country must represent a progression beyond the earlier contributions, and reflect the highest possible ambition, of that country. Stalling climate action after 2030 would be in contradiction with the provisions of the Paris Agreement.

Under these assumptions of continued climate action, the 2030 unconditional-INDC emission range is roughly consistent with a median warming relative to pre-industrial levels of $2.6-3.1^{\circ} \mathrm{C}$ (median, $2.9^{\circ} \mathrm{C}$; full scenario projection uncertainty, $2.2-3.5^{\circ} \mathrm{C}$; Table 1 , Fig. $2 \mathrm{~b}$, Supplementary Fig. 1), with warming continuing its increase afterwards. This is an improvement on the current-policy and no-policy baseline scenarios, whose median projections suggest about $3.2^{\circ} \mathrm{C}$ and more than $4^{\circ} \mathrm{C}$ of temperature rise by 2100 , respectively. The successful implementation of all conditional INDCs would decrease our median estimate by an additional $0.2^{\circ} \mathrm{C}$, but keeps the outcome far from the world the Paris Agreement is aiming for, with well-below $2^{\circ} \mathrm{C}$ and $1.5^{\circ} \mathrm{C}$ of warming. Moreover, all above-mentioned values represent median projections. Because the climate response to GHG emissions remains uncertain ${ }^{46}$, it is also possible that substantially higher temperatures will materialize with compelling likelihoods (Table 1). For example, at the 66th percentile level, warming under the unconditional INDCs is projected to be about $0.3^{\circ} \mathrm{C}$ higher $\left(3.2^{\circ} \mathrm{C}\right.$, with a range of $\left.2.9-3.4^{\circ} \mathrm{C}\right)$. Finally, the INDC cases that we assess here will exceed the available carbon budget for keeping warming to below $2{ }^{\circ} \mathrm{C}$ by 2030 with $66 \%$ probability (that is, roughly 
a

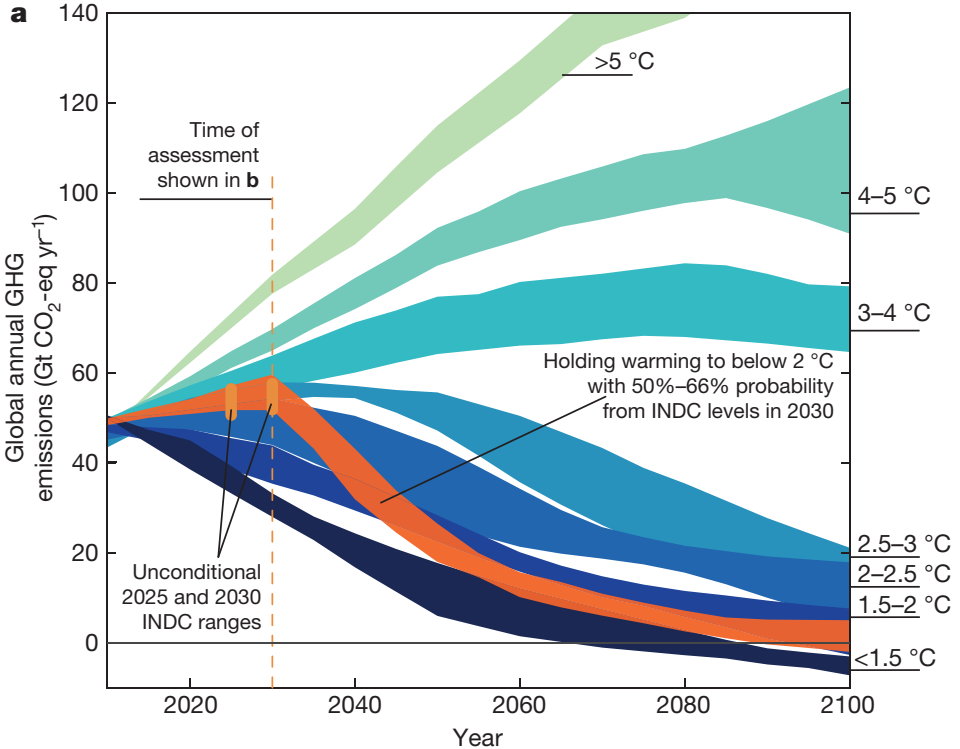

b

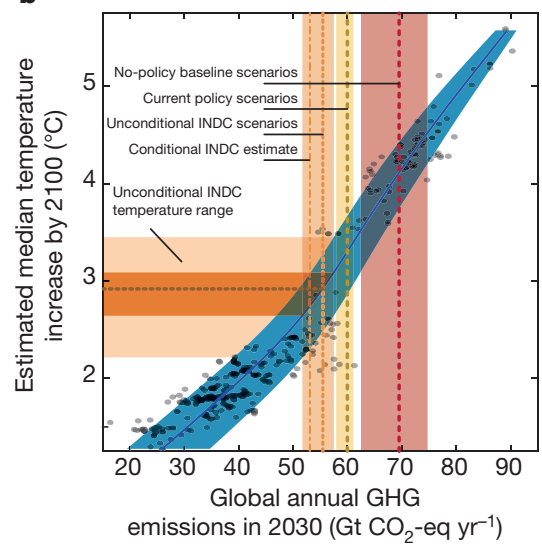

c

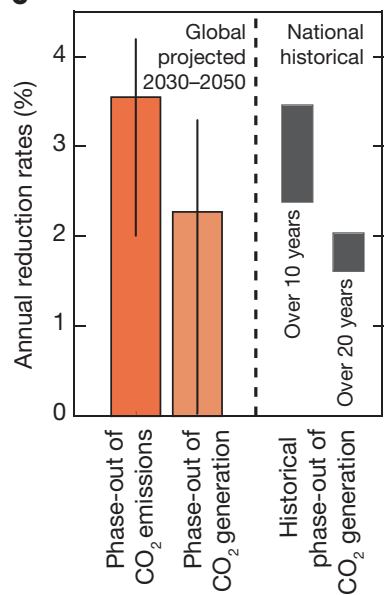

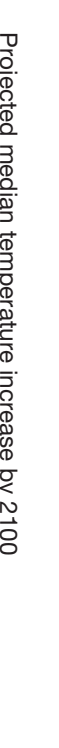
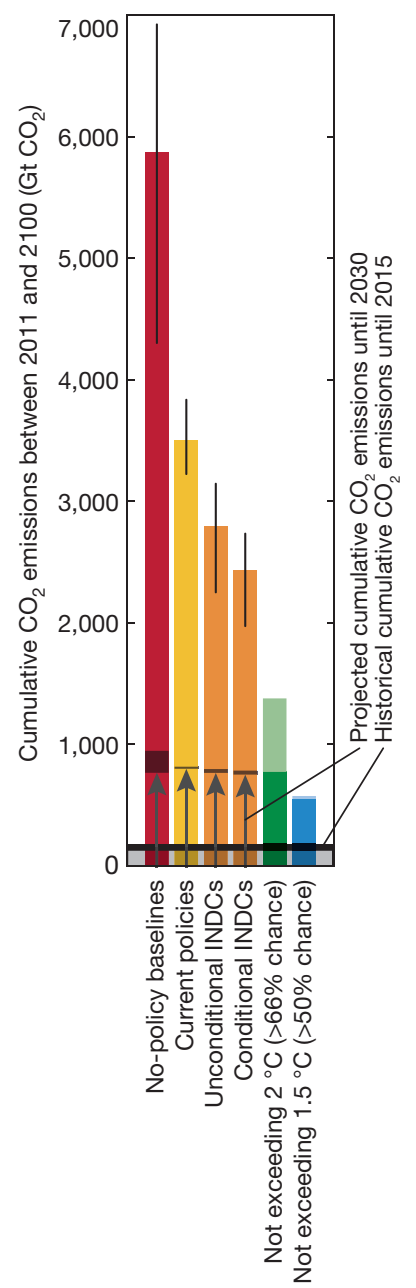

Figure 2 | Temperature implications of current INDCs. a, GHG emission ranges (20th-80th percentile) of scenarios from the IPCC AR5 Scenario Database with constant policy assumptions from 2010 onwards (blueto-green shaded ranges), grouped per estimated median global-mean temperature increase in 2100 relative to pre-industrial levels (1850-1900), and range of the scenario subset limiting warming to below $2^{\circ} \mathrm{C}$ by 2100 with 50\%-66\% likelihood (dark orange) from year-2030 INDC levels. The vertical orange lines show the unconditional INDC range in 2025 and 2030, as shown in Fig. 1 . The $2{ }^{\circ} \mathrm{C}$ range shown in Fig. 1 starts global least-cost mitigation action in 2020 instead of 2010 and is not included here. b, Relationship between global GHG emission levels in 2030 and median global-mean temperature increase by 2100 based on scenarios shown in a. Each dot represents a single scenario. The blue line shows a smoothing spline fit $\left(R^{2} \approx 0.93\right)$ and the blue-shaded area shows fits to the 5th and 95th percentile over all points. Comparing the central fit with the range of year-2030 GHG emissions implied by the unconditional INDCs shows that INDCs are roughly consistent with a median warming of

750-800 Gt $\mathrm{CO}_{2}$-eq implied emissions under the INDCs during the 2011-2030 period compared to the 750-1,400 Gt $\mathrm{CO}_{2}$-eq available; Supplementary Text 3, Supplementary Table 6, Fig. 2d). The budget for never exceeding $1.5^{\circ} \mathrm{C}$ with a $50 \%$ probability (550-600 Gt $\mathrm{CO}_{2}$-eq) will be entirely gone, indicating that active removal of $\mathrm{CO}_{2}$ at a later point in time will be required to return to within this budget (Supplementary Table 6). Median warming under the INDCs is projected to cross the $1.5^{\circ} \mathrm{C}$ and $2{ }^{\circ} \mathrm{C}$ limits by 2030-2045 and 2045-2075, respectively (Supplementary Fig. 4).

The question thus arises whether global temperature rise can be kept to well below $2^{\circ} \mathrm{C}$ with accelerated action after 2030 . Global scenarios that aim to keep warming to below $2{ }^{\circ} \mathrm{C}$ and that achieve this objective
2.6-3. $1^{\circ} \mathrm{C}$ by 2100 (horizontal dark-orange range), and a $2.2-3.5^{\circ} \mathrm{C}$ range including scenario projection uncertainty (horizontal light-orange range). Vertical dashed lines and shaded regions show year-2030 GHG estimates for the various scenario sets. c, Annual $\mathrm{CO}_{2}$ reduction rates modelled in scenarios limiting warming to below $2{ }^{\circ} \mathrm{C}$ from year-2030 INDC levels (dark-orange range in a; bars, median; vertical lines, spread across all available scenarios) and historical examples (range for France, Sweden and Denmark is based on ref. 74; see Supplementary Text 4). d, Implied cumulative carbon emissions including uncertainties, and comparison to budget ranges for not exceeding $1.5^{\circ} \mathrm{C}$ (with $50 \%$ probability) and $2{ }^{\circ} \mathrm{C}$ (with 66\% probability) from refs 9 and 11 (dark bar, lower estimate; light bar, high-range estimate). Historical estimates are from ref. 75. Vertical lines show the range due to scenario spread (Supplementary Text 3 and Supplementary Table 6). Arrows and bars in the first four columns show the projected cumulative $\mathrm{CO}_{2}$ emissions until 2030 for each respective scenario.

from 2030 GHG emissions similar to those from the INDC range have been assessed in detail by recent large-scale model-comparison projects ${ }^{16,40}$. Our re-analysis of these scenarios shows that even with accelerated action after 2030, options to keep warming to well below $2{ }^{\circ} \mathrm{C}$ from current INDCs are severely limited, particularly if some key mitigation technologies do not scale up as anticipated. This is easy to understand if one appreciates that even if all INDCs are successfully implemented by 2030 , the $2{ }^{\circ} \mathrm{C}$ carbon budget might already be virtually exhausted by that time (see earlier and Fig. 2d). The Paris Agreement does not define precisely what its "well-below $2^{\circ} \mathrm{C}$ " aim means. Typically, policymakers in the UNFCCC have been concerned about limiting warming to below $2{ }^{\circ} \mathrm{C}$ 
with $>66 \%$ probability ${ }^{47}$. However, from current INDC levels, all available internally consistent scenarios manage to limit warming to below $2{ }^{\circ} \mathrm{C}$ with only a lower, $50 \%-66 \%$ probability, increasing the risks of climate change impacts. No scenarios are available that are consistent with both the current INDCs and $1.5^{\circ} \mathrm{C}$ warming limit with $50 \%$ probability.

The available scenarios show rapidly declining emissions after 2030, with global $\mathrm{CO}_{2}$ emissions from energy- and industry-related sources reaching net-zero levels between 2060 and 2080. The global economy is thus assumed to fully decarbonize ${ }^{17}$ in the time span of three to five decades and from 2030 levels that are higher than today's. Furthermore, about two thirds of these scenarios achieve a balance of global GHG emissions (as mentioned in the Paris Agreement) between 2080 and 2100. Because some non- $\mathrm{CO}_{2}$ emissions are virtually impossible to eliminate entirely (for example, those from specific agricultural sources ${ }^{39}$ ), reaching such a balance will involve net-negative $\mathrm{CO}_{2}$ emissions ${ }^{48}$ at a global scale to compensate for any residual non- $\mathrm{CO}_{2}$ emissions ${ }^{17}$, resulting in gradual decline in global-average temperatures increase over time. Technologies that might be able to achieve this feat are still surrounded by important uncertainties (see below). In general, lower near-term emissions allow for a later timing of reaching global net-zero $\mathrm{CO}_{2}$ emissions ${ }^{17}$ (see $1.5-2{ }^{\circ} \mathrm{C}$ versus dark-orange range in Fig. 2a) and, moreover, reduce the overall future reliance on negative emissions technologies ${ }^{16,40,41}$.

To illustrate the challenges involved, we take a critical look at some characteristics of the scenarios. Scenarios that broadly follow the INDCs until 2030 and still manage to keep warming to below $2{ }^{\circ} \mathrm{C}$ (with $50 \%$ $66 \%$ probability only) are associated with a very rapid decline in $\mathrm{CO}_{2}$ emissions from energy- and industry-related sources after 2030. The decarbonization between 2030 and 2050 is particularly decisive in these scenarios $^{40,45}$. For this period, the scenarios show average rates of decline in annual emissions of about $3.5 \%(2.0 \%-4.2 \%$, full range across scenarios; Supplementary Text 4). To understand what this means in a historical context, it makes sense to distinguish between (1) the phase-out of $\mathrm{CO}_{2}$ generation over time (a proxy for the reduction in fossil-fuel use and upscaling of low-carbon energy sources) and (2) the required upscaling of industrial-scale $\mathrm{CO}_{2}$ sequestration with carbon capture and geological storage (CCS) technologies ${ }^{49,50}$. The latter mitigation option has not been applied in the past. It can thus be seen as an additional technological option that is included in scenarios, but that did not contribute to the past experiences.

In the $2{ }^{\circ} \mathrm{C}$ scenarios that start from INDC levels in 2030 (dark-orange range in Fig. 2a), $\mathrm{CO}_{2}$ generation is reduced at a median annual rate of about $2.3 \%(0.0 \%-3.3 \%$, full range) between 2030 and 2050 . Historically, countries have been able to achieve reductions in $\mathrm{CO}_{2}$ generation at rates of about $2 \%-3 \%$ per year as a result of dedicated (energy-security) policies ${ }^{40}$ (Fig. 2c; Supplementary Text 4). Limiting warming to below $2{ }^{\circ} \mathrm{C}$ from year-2030 INDC levels thus implies that the pace of such a precipitated phase-out of fossil-fuel use needs to be replicated globally. These historical reductions were all achieved for non-climate reasons, with a focus on energy security and not on emissions reductions. There is thus no clear historical analogue for reductions under a dedicated and stringent climate policy. The challenge remains nevertheless important. This becomes even clearer when appreciating that all historical analogues for reductions were achieved in highly developed countries, such as France, Sweden and Denmark. Achieving similar results in developing countries, with energy-intensive sectors that are still growing and with weaker institutional frameworks, higher investment risks and less capacity, will be more difficult ${ }^{43}$, but, at the same time, readily available low-cost zero-carbon alternatives could also allow those economies to leap-frog carbon-intensive development in some sectors.

Scenarios complement the global phase-out of $\mathrm{CO}_{2}$ generation with a scale-up of CCS infrastructure to capture and geologically store part of the $\mathrm{CO}_{2}$ that continues to be generated. This scale-up is massive in scenarios that limit warming to below $2^{\circ} \mathrm{C}$ from INDC levels. Because such scenarios have limited CCS deployment until 2030, the annual rate of $\mathrm{CO}_{2}$ sequestration is assumed to increase 10 - to $>100$-fold in the 2030 2050 period, reaching about $10 \mathrm{Gt} \mathrm{CO}_{2} \mathrm{yr}^{-1}$ in 2050 (8-14 Gt CO $2 \mathrm{yr}^{-1}$ range). To put this challenge into perspective, about $85 \mathrm{GW}$ (measured in coal-equivalent power generation; Supplementary Text 4) of new CCS capacity would need to be installed each year to capture this amount by 2050, which corresponds roughly to the combined capacity of solar and wind power generation that is annually globally installed today ${ }^{51,52}$ (Supplementary Fig. 2). Altogether, the global energy-system transition that is required to limit warming to well below $2{ }^{\circ} \mathrm{C}$ and further to $1.5^{\circ} \mathrm{C}$ is unprecedented.

Finally, scenarios often combine CCS with biomass energy (abbreviated as BECCS) as a way of actively capturing and removing $\mathrm{CO}_{2}$ from the atmosphere. Although in principle this is technically possible, deployment of such technologies at scale is untested, and could be controversial because of public acceptance ${ }^{53}$ or because of their competition with food production over land and water ${ }^{53,54}$. A recent review ${ }^{54}$ showed that, assuming agricultural practices and yields do not change over the twenty-first century, removing $\mathrm{CO}_{2}$ could require large amounts of land. At the same time, other assessments ${ }^{39,55-57}$ concluded that it might be possible to produce the required amount of bio-energy in a sustainable way (up to $300 \mathrm{EJ} \mathrm{yr}^{-1}$, see box 11.5 in ref. 39). The importance of the land-use question for policy is highlighted by the decision of the IPCC to dedicate one of its three upcoming Special Reports to questions of sustainable land management and food security. Exploring futures in which a global balance of GHG emissions can be achieved in the second half of this century with technically feasible and societally acceptable technologies represents a major research challenge emerging from the Paris Agreement ${ }^{58}$. This challenge is particularly relevant to policy, because limiting emissions in 2030 does not only increase the chances of attaining the $2{ }^{\circ} \mathrm{C}$ target, but also reduces the need to rely on unproven, potentially risky or controversial technologies in the future ${ }^{16,40,59}$.

\section{Decreasing the post -2030 challenge}

The post- 2030 challenge to limit warming to below $2{ }^{\circ} \mathrm{C}$ from current INDC levels is daunting, and pursuing efforts for $1.5^{\circ} \mathrm{C}$ even more so. However, the overall challenge can be minimized by additional GHG reductions in the near-term ${ }^{16,40,41}$. In this context, near-term means before and by 2030. Besides (i) the option of countries increasing the overall ambition of their INDCs, we identify several other options that can contribute to this (see Table 2 for an overview). The options include: (ii) increasing the coverage of INDCs to more sectors and gases; (iii) including international sectors such as aviation and international maritime transport; (iv) implementing measures that enable overdelivery on the INDCs; (v) increasing contributions to international climate finance and international cooperation on technology development, transfer and diffusion; and (vi) promoting and implementing additional national, sub-national and non-state initiatives. These options are not fully additional; some of them overlap (strongly) with the INDCs, and their precise contributions thus remain speculative (see Table 2). However, several indications suggest that such an increase in ambition is possible.

First, increasing ambition over time is a key component of the Paris Agreement framework. For example, countries are requested to submit new-or update existing - contributions that should represent a progression beyond their earlier commitments. The certainty of the new global climate agreement, together with the improving cost and availability of low-carbon technologies ${ }^{60}$, might help countries to consider strengthening their post-2020 contributions. Second, countries can undertake further domestic measures. Because many countries have undergone national stakeholder processes in preparation of their INDCs, they could now be in a better position to consider additional policies ${ }^{61}$. Sub-national actors such as cities and regional governments may take further action, and non-state actors can also help to overachieve INDCs. The Paris conference saw unprecedented willingness to act by these stakeholders, with more than 1,000 non-state actors signing the Paris Pledge for Action (http://www.parispledgeforaction.org/), signalling that they are willing to support efforts to meet and exceed the ambition of governments for keeping the world on a $2^{\circ} \mathrm{C}$ trajectory. This role of non-Party stakeholders 


\begin{tabular}{|c|c|c|}
\hline Option & Description & Possible impact on global emissions in 2030 \\
\hline $\begin{array}{l}\text { (i) Increasing ambition of existing } \\
2025 \text { and } 2030 \text { contributions }\end{array}$ & $\begin{array}{l}\text { The outcome of the Paris climate summit provides several opportunities to } \\
\text { increase ambition of national contributions by } 2030 \text {, for example, through } \\
\text { consecutive five-year cycles during which national contributions increase in } \\
\text { ambition. }\end{array}$ & $\begin{array}{l}10 \mathrm{Gt} \mathrm{CO}_{2} \text {-eq } \mathrm{yr}^{-1} \\
\text { Theoretical potential to embark on a } \\
\text { least-cost } 2^{\circ} \mathrm{C} \text { pathway after } 2020^{16} \text {. }\end{array}$ \\
\hline $\begin{array}{l}\text { (ii) Increasing coverage of sectors } \\
\text { and gases }\end{array}$ & $\begin{array}{l}\text { Some countries cover only part of their total GHG emissions and some sectors } \\
\text { in their contributions; for example, some contributions apply only to } \mathrm{CO}_{2} \text { and } \\
\text { not to other GHGs. Extending INDCs to all sectors and gases would increase the } \\
\text { global coverage of INDCs. }\end{array}$ & $0.1-1 \mathrm{Gt} \mathrm{CO}_{2}$-eq $\mathrm{yr}^{-1 \dagger}$ \\
\hline (iii) Including international sectors & $\begin{array}{l}\text { At present, the contributions cover only countries. International sectors, such as } \\
\text { international aviation and maritime transport can also be included. These sectors } \\
\text { covered around } 2 \% \text { of global emissions in } 2010^{\ddagger} \text {, with an increasing trend. }\end{array}$ & 0.1-1 Gt $\mathrm{CO}_{2}$-eq $\mathrm{yr}^{-1}$ ref. 71 ) \\
\hline $\begin{array}{l}\text { (iv) Implementing domestic } \\
\text { measures that enable } \\
\text { over-delivery on the INDCs* }\end{array}$ & $\begin{array}{l}\text { Countries can implement domestic measures that go beyond the actions } \\
\text { described in the current INDCs. }\end{array}$ & 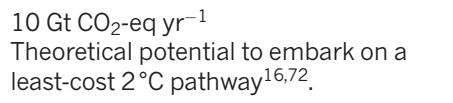 \\
\hline $\begin{array}{l}\text { (v) Increasing climate finance and } \\
\text { international cooperation* }\end{array}$ & $\begin{array}{l}\text { Additional international climate finance and cooperation on technology } \\
\text { development, transfer and diffusion could help to (over-)achieve the } \\
\text { conditional end of the national contributions. }\end{array}$ & 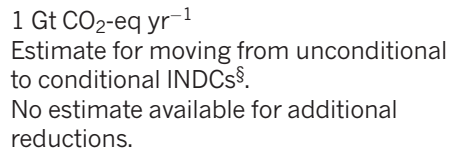 \\
\hline $\begin{array}{l}\text { (vi) Implementing international } \\
\text { cooperative initiatives }{ }^{*}\end{array}$ & $\begin{array}{l}\text { Action could be implemented by ambitious sub-national or regional } \\
\text { governments, companies, organizations, non-governmental organisations and } \\
\text { citizens to further reduce emissions. The amount of overlap of these initiatives } \\
\text { with national contributions remains unclear. }\end{array}$ & $\begin{array}{l}1 \mathrm{Gt} \mathrm{CO}_{2} \text {-eq } \mathrm{yr}^{-1} \text { in } 2020^{\|} \\
\text {No comprehensive estimates available } \\
\text { for } 2030 \text {. }\end{array}$ \\
\hline
\end{tabular}

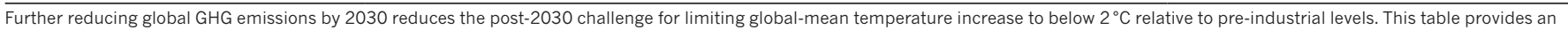

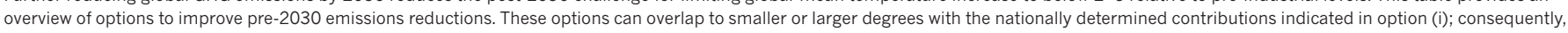
they are not fully additive. Estimates of the potential impact on global emissions are highly uncertain and therefore only the expected order of magnitude (nearest power of 10 ) is provided for each option.

"Options that overlap to smaller or larger degrees with option (i).

†See Supplementary Text 2.

¥Source: Emission Database for Global Atmospheric Research (EDGAR), http://edgar.jrc.ec.europa.eu/.

See Supplementary Table 5.

"Estimate based on refs 64, 65, 73.

is acknowledged more clearly than ever before in the official Paris decisions. However, although the theoretical potential of these activities is huge, their additional impact is very hard to quantify, and it remains unclear whether these initiatives are additional to the already pledged national contributions ${ }^{62-65}$.

\section{Outlook}

Covering most of the world's GHG emissions with climate plans in the form of voluntarily submitted INDCs is a historic achievement. The Paris Agreement requires the submission of successive, increasingly ambitious, nationally determined contributions that are subject to strong transparency guidelines, as well as a global stock-take, in the light of equity and science, every five years. The optimism accompanying this process has to be carefully balanced against the important challenges that current INDCs imply for post-2030 emissions reductions. Even starting today, limiting warming to no more than $2{ }^{\circ} \mathrm{C}$ relative to pre-industrial levels constitutes a societal challenge; at the same time, the warming projected from current INDCs constitutes an important challenge on its own in terms of coping with climate impacts. The nationally determined contributions constitute a new era for climate policy under the Paris Agreement, and represent both an invitation and a call for further action. Furthering greater reductions in the coming decade and preparing for a global transformation of development pathways is critical.

Two developments look particularly promising to us. First, it becomes increasingly clear to decision-makers that measures to reduce GHG emissions have multiple socio-economic benefits ${ }^{66}$. The action by virtually all countries improves prospects for further collective action, which must be the fundamental basis of any adequate response to climate change. Therefore, it becomes easier to conceive additional measures or strengthen existing ones. Second, the recent unprecedented engagement of non-state actors such as businesses, citizens and religious organizations illustrates a more profuse awareness and an increased momentum for climate action. Given the large potential for emissions reductions as a result of both of these options, supporting and enabling national and non-state action will be critical. This insight also opens important avenues for future research and assessment. The research community will have to break from a one-sided climate-policy-centred approach and develop new concepts and frameworks that further the achievement of a portfolio of societal objectives, including climate, food and energy security, public health, and other goals of the sustainable development agenda ${ }^{67}$. Charting development pathways that can hold warming well below $2{ }^{\circ} \mathrm{C}$ will thus require a renewed effort of the social and physical science communities alike.

\section{Received 1 September 2015; accepted 9 May 2016.}

1. UNFCCC. Adoption of the Paris Agreement. Report No. FCCC/CP/2015/L.9/ Rev.1, http://unfccc.int/resource/docs/2015/cop21/eng/109r01.pdf (UNFCCC, 2015).

2. UNFCCC. INDCs as communicated by Parties. http://www4.unfccc.int/ submissions/indc/Submission\%20Pages/submissions.aspx (2015).

3. UNFCCC. United Nations Framework Convention on Climate Change. Report No. FCCC/INFORMAL/84, https://unfccc.int/resource/docs/convkp/conveng.pdf (UNFCCC, 1992).

4. Knutti, R., Rogeli, J., Sedláček, J. \& Fischer, E. M. A scientific critique of the two-degree climate change target. Nat. Geosci. 9, 13-18 (2016).

5. Randalls, S. History of the $2^{\circ} \mathrm{C}$ climate target. Wiley Interdiscip. Rev. Clim. Change 1, 598-605 (2010) An introduction to the roots of the $2{ }^{\circ} \mathrm{C}$ climate target and its development over the past decades.

6. Collins, M. et al. in Climate Change 2013: The Physical Science Basis. Contribution of Working Group I to the Fifth Assessment Report of the Intergovernmental Panel on Climate Change (eds Stocker T. F. et al.) 1029-1136 (Cambridge Univ. Press, 2013).

7. Matthews, H. D. \& Caldeira, K. Stabilizing climate requires near-zero emissions. Geophys. Res. Lett. 35, L04705 (2008).

8. Knutti, R. \& Rogeli, J. The legacy of our $\mathrm{CO}_{2}$ emissions: a clash of scientific facts, politics and ethics. Clim. Change 133, 361-373 (2015).

9. IPCC. Climate Change 2014: Synthesis Report. Contribution of Working Groups I, II and III to the Fifth Assessment Report of the Intergovernmental Panel on Climate Change (IPCC, 2014).

The most recent intergovernmental report synthesizing our current understanding of the physical science and impacts of, and possible solutions to avoid, climate change.

10. Meinshausen, M. et al. Greenhouse-gas emission targets for limiting global warming to $2^{\circ} \mathrm{C}$. Nature $458,1158-1162$ (2009).

11. Rogelj, J. et al. Differences between carbon budget estimates unravelled. Nat. Clim. Change 6, 245-252 (2016). 
12. Friedlingstein, $P$. et al. Persistent growth of $\mathrm{CO}_{2}$ emissions and implications for reaching climate targets. Nat. Geosci. 7, 709-715 (2014).

13. Rogelj, J., McCollum, D. L., Reisinger, A., Meinshausen, M. \& Riahi, K. Probabilistic cost estimates for climate change mitigation. Nature 493, 79-83 (2013).

14. Luderer, G. et al. Economic mitigation challenges: how further delay closes the door for achieving climate targets. Environ. Res. Lett. 8, 034033 (2013).

15. Rogelj, J. et al. Energy system transformations for limiting end-of-century warming to below $1.5^{\circ} \mathrm{C}$. Nat. Clim. Change 5, 519-527 (2015).

16. Clarke, L. et al. in Climate Change 2014: Mitigation of Climate Change. Contribution of Working Group III to the Fifth Assessment Report of the Intergovernmental Panel on Climate Change (eds Edenhofer O. et al.) 413-510 (Cambridge Univ. Press, 2014).

17. Rogelj, J. et al. Zero emission targets as long-term global goals for climate protection. Environ. Res. Lett. 10, 105007 (2015).

Study providing insights about the consistency between Article 2 and Article 4 of the UNFCCC Paris Agreement.

18. UNEP. The Emissions Gap Report 2015 http://uneplive.unep.org/media/docs/ theme/13/EGR_2015_301115_lores.pdf (UNEP, 2015).

An annual assessment tracking climate policy action over the past six years, which provided the basis for the analysis presented in this Perspective.

19. Climate Analytics, Ecofys, NewClimate Institute \& PIK. Climate pledges will bring $2.7^{\circ} \mathrm{C}$ of warming, potential for more action. Climate Action Tracker http://climateactiontracker.org/news/253/Climate-pledges-will-bring-2.7C-ofwarming-potential-for-more-action.html (2015).

20. Admiraal, A. et al. Assessing Intended Nationally Determined Contributions to the Paris Climate Agreement - What are the Projected Global and National Emission Levels for 2025-2030? Report No. PBL 1879, http://www.pbl.nl/en/ publications/assessing-intended-nationally-determined-contributions-to-theparis-climate-agreement (PBL Netherlands Environmental Assessment Agency, 2015).

21. IEA. World Energy Outlook 2015. International Energy Agency http://www. worldenergyoutlook.org/resources/energyandclimatechange/ (2015)

22. Boyd, R., Cranston Turner, J. \& Ward, B. Intended Nationally Determined Contributions: What are the Implications for Greenhouse Gas Emissions in 2030? http://www.Ise.ac.uk/Granthamlnstitute/wp-content/uploads/2015/10/ Boyd_Turner_and_Ward_policy_paper_October_2015.pdf (Centre for Climate Change Economics and Policy, and Grantham Research Institute on Climate Change and the Environment, 2015).

23. Meinshausen, M. INDC Factsheets. Australian-German Climate and Energy College http://climate-energy-college.net/indc-factsheets (2015).

24. DEA. Analyzing the 2030 emissions gap. Danish Energy Agency http://www.ens. dk/gap (2015)

25. Climate Interactive. Climate Scoreboard. Climate Interactive https://www. climateinteractive.org/programs/scoreboard/ (2015).

26. Fawcett, A. A. et al. Can Paris pledges avert severe climate change? Science 350, 1168-1169 (2015).

27. UNFCCC. Synthesis Report on the Aggregate Effect of the Intended Nationally Determined Contributions. Report No. FCCC/CP/2015/7, http://unfccc.int/ resource/docs/2015/cop21/eng/07.pdf (UNFCCC, 2015).

28. Kitous A. \& Keramidas K. Analysis of Scenarios Integrating the INDCs https:// ec.europa.eu/jrc/sites/default/files/JRC97845.pdf (Joint Research Centre, 2015).

29. den Elzen, M. et al. Enhancing Mitigation Ambitions in the Major Emitting Countries: Analysis of Current and Potential Climate Policies. Report No. PBL 1631, http://www.pbl.nl/en/publications/enhancing-mitigation-ambitions-inthe-major-emitting-countries-analysis-of-current-and-potential-climate-policies (PBL Netherlands Environmental Assessment Agency, 2015).

30. JRC/PBL. EDGAR version 4.2FT2012 http://edgar.jrc.ec.europa.eu/overview. php?v=GHGts1990-2012 (Joint Research Centre of the European Commission, PBL Netherlands Environmental Assessment Agency, 2014).

31. Damassa, T. et al. Interpreting INDCs: Assessing Transparency of Post-2020 Greenhouse Gas Emissions Targets for 8 Top-Emitting Economies (Working Paper) http://www.wri.org/sites/default/files/WRI_WP_InterpretingINDCs.pdf (World Resources Institute, 2015).

32. World Resources Institute. Paris Contributions Map. CAIT Climate Data Explorer http://cait.wri.org/indc/ (2015).

33. ICAO. Assembly Resolutions in Force (as of 4 October 2013). Report No. 10022, http://www.icao.int/publications/documents/10022 en.pdf (ICAO, 2014).

34. den Elzen, M. G. J. et al. Greenhouse gas emissions from current and enhanced policies of China until 2030: can emissions peak before 2030? Energy Policy 89, 224-236 (2016)

35. Sha, F., Ji, Z. \& Linwei, L. An Analysis of China's INDC http://www.chinacarbon. info/wp-content/uploads/2015/07/Comments-on-Chinas-INDC.pdf (China National Center for Climate Change Strategy and International Cooperation (NCSC), 2015)

36. Grassi G. \& Dentener F. Quantifying the Contribution of the Land Use Sector to the Paris Climate Agreement. Report No. EUR 27561, http://publications.jrc. ec.europa.eu/repository/bitstream/JRC98451/jrc\%20lulucf-indc\%20report. pdf (European Union, JRC Science Hub, 2015).

37. Blanco, G. et al. in Climate Change 2014: Mitigation of Climate Change. Contribution of Working Group III to the Fifth Assessment Report of the Intergovernmental Panel on Climate Change (eds Edenhofer O. et al.) 351-411 (Cambridge Univ. Press, 2014).

38. Rogelj, J., Hare, W., Chen, C. \& Meinshausen, M. Discrepancies in historical emissions point to a wider 2020 gap between $2^{\circ} \mathrm{C}$ benchmarks and aggregated national mitigation pledges. Environ. Res. Lett. 6, 024002 (2011).
39. Smith, P. et al. in Climate Change 2014: Mitigation of Climate Change. Contribution of Working Group III to the Fifth Assessment Report of the Intergovernmental Panel on Climate Change (eds Edenhofer O. et al.) 811-922 (Cambridge Univ. Press, 2014).

40. Riahi, K. et al. Locked into Copenhagen pledges - implications of short-term emission targets for the cost and feasibility of long-term climate goals. Technolog. Forecast. Soc. Change 90, 8-23 (2015).

41. Rogelj, J., McCollum, D. L., O'Neill, B. C. \& Riahi, K. 2020 emissions levels required to limit warming to below $2^{\circ} \mathrm{C}$. Nat. Clim. Change $\mathbf{3}, 405-412$ (2013).

42. Kriegler, E. et al. Making or breaking climate targets: The AMPERE study on staged accession scenarios for climate policy. Technolog. Forecast. Soc. Change 90, 24-44 (2015).

43. Iyer, G. C. et al. Improved representation of investment decisions in assessments of $\mathrm{CO}_{2}$ mitigation. Nat. Clim. Change 5, 436-440 (2015).

44. Roehrl, R. A. \& Riahi, K. Technology dynamics and greenhouse gas emissions mitigation: a cost assessment. Technol. Forecast. Soc. Change 63, 231-261 (2000)

45. Eom, J. et al. The impact of near-term climate policy choices on technology and emission transition pathways. Technolog. Forecast. Soc. Change 90, 73-88 (2015)

46. Stocker, T. F. et al. in Climate Change 2013: The Physical Science Basis. Contribution of Working Group I to the Fifth Assessment Report of the Intergovernmental Panel on Climate Change (eds Stocker T. F. et al.) 33-115 (Cambridge Univ. Press, 2013).

47. UNFCCC. Establishment of an Ad Hoc Working Group on the Durban Platform for Enhanced Action. Draft decision -/CP.17, https://unfccc.int/files/meetings/ durban_nov_2011/decisions/application/pdf/cop17_durbanplatform.pdf (UNFCCC, 2011)

48. Obersteiner, M. et al. Managing climate risk. Science 294, 786-787 (2001)

49. Scott, V., Haszeldine, R. S., Tett, S. F. B. \& Oschlies, A. Fossil fuels in a trillion tonne world. Nat. Clim. Change 5, 419-423 (2015).

50. IPCC. IPCC Special Report on Carbon Dioxide Capture and Storage. Prepared by Working Group III of the Intergovernmental Panel on Climate Change (eds Metz, B. et al.) (Cambridge Univ. Press, 2005).

51. Global Wind Energy Council. Global Statistics http://www.gwec.net/globalfigures/graphs/ [accessed 15 October 2015] (2015).

52. SolarPower Europe. Global Market Outlook For Solar Power / 2015 - 2019 http://helapco.gr/pdf/Global_Market_Outlook_2015 -2019 Ir_v23.pdf (SolarPower Europe, 2015).

53. Upham, P. \& Roberts, T. Public perceptions of CCS: emergent themes in pan-European focus groups and implications for communications. Int. J. Greenh. Gas Control 5, 1359-1367 (2011).

54. Smith, P. et al. Biophysical and economic limits to negative $\mathrm{CO}_{2}$ emissions. Nat. Clim. Change 6, 42-50 (2016).

55. Creutzig, F. et al. Bioenergy and climate change mitigation: an assessment. GCB Bioenergy 7, 916-944 (2015).

56. Coelho, S. T. et al. in Global Energy Assessment: Toward a Sustainable Future (eds Johannsson, T. B. et al.) Ch. 20, 1459-1525 (Cambridge Univ. Press, International Institute for Applied Systems Analysis, 2012).

57. IPCC. Special Report on Renewable Energy Sources and Climate Change Mitigation (eds Edenhofer, O. et al.) http://www.ipcc.ch/report/srren/ (Cambridge Univ. Press, 2011).

58. Rogelj, J. \& Knutti, R. Geosciences after Paris. Nat. Geosci. 9, 187-189 (2016)

59. Iyer, G. C. et al. The contribution of Paris to limit global warming to $2{ }^{\circ} \mathrm{C}$. Environ. Res. Lett. 10, 125002 (2015).

60. Cronin C. et al. Faster and Cleaner: Decarbonization in the Power and Transport Sectors is Surpassing Predictions and Offering Hope for Limiting Warming to $2^{\circ} \mathrm{C}$ http://www.climateworks.org/wp-content/uploads/2015/11/Faster-CleanerDecarbonization-in-the-Power-Transport-Sectors.pdf (ClimateWorks, NewClimate Institute, Ecofys, Climate Analytics, 2015)

61. Day, T., Röser, F., Tewari, R., Kurdziel, M. \& Höhne, N. Preparation of Intended Nationally Determined Contributions (INDCs) as a Catalyst for National Climate Action http://mitigationpartnership.net/sites/default/files/indc_as_catalyst.pdf (NewClimate Institute, 2015)

62. Weischer, L., Morgan, J. \& Patel, M. Climate clubs: can small groups of countries make a big difference in addressing climate change? Rev. Eur. Community Int. Environ. Law 21, 177-192 (2012).

63. Blok, K., Höhne, N., van der Leun, K. \& Harrison, N. Bridging the greenhousegas emissions gap. Nat. Clim. Change 2, 471-474 (2012).

64. Hsu, A., Moffat, A. S., Weinfurter, A. J. \& Schwartz, J. D. Towards a new climate diplomacy. Nat. Clim. Change 5, 501-503 (2015).

65. UNEP. Climate Commitments of Subnational Actors and Business: A Quantitative Assessment of their Emission Reduction Impact. Report No. DEW/1917/NA, http://apps.unep.org/redirect.php?file=/publications/ pmtdocuments/-Climate_Commitments_of_Subnational_Actors_and_ Business-2015CCSA_2015.pdf.pdf (United Nations Environment Programme, 2015).

66. IPCC in Climate Change 2014: Mitigation of Climate Change. Contribution of Working Group III to the Fifth Assessment Report of the Intergovernmental Panel on Climate Change (eds Edenhofer, O. et al.) 1-33 (Cambridge Univ. Press, 2014).

67. UN General Assembly. Transforming our World: the 2030 Agenda for Sustainable Development. Report No. A/RES/70/1, http://www.un.org/ga/search/view_doc asp?symbol=A/RES/70/1\&Lang=E (United Nations, 2015). 
68. Rogelj, J., Meinshausen, M., Sedláček, J. \& Knutti, R. Implications of potentially lower climate sensitivity on climate projections and policy. Environ. Res. Lett. 9, 031003 (2014)

69. Rogelj, J., Meinshausen, M. \& Knutti, R. Global warming under old and new scenarios using IPCC climate sensitivity range estimates. Nat. Clim. Change 2 248-253 (2012)

70. Meinshausen, M., Raper, S. C. B. \& Wigley, T. M. L. Emulating coupled atmosphereocean and carbon cycle models with a simpler model, MAGICC6 - part 1: model description and calibration. Atmos. Chem. Phys. 11, 1417-1456 (2011)

71. Cames, M., Graichen, J., Siemons, A. \& Cook, V. Emission Reduction Targets for International Aviation and Shipping. Report No. IP/A/ENVI/2015-11, http:// www.europarl.europa.eu/RegData/etudes/STUD/2015/569964/IPOL STU(2015)569964_EN.pdf (European Parliament's Committee on Environment, Public Health and Food Safety, 2015).

72. Fekete, H. et al. The Impact of Good Practice Policies on Regional and Global Greenhouse Gas Emissions https://newclimateinstitute.files.wordpress. com/2015/07/task2c_goodpracticeanalysis_july_2015.pdf (NewClimate Institute, PBL Netherlands Environmental Assessment Agency, International Institute for Applied Systems Analysis, 2015).

73. Roelfsema, M., Harmsen, M., Olivier, J. \& Hof, A. F. Climate Action Outside the UNFCCC. Report No. PBL 1188, http://www.pbl.nl/sites/default/files/cms/ pbl-2015-climate-action-outside-the-unfccc 01188.pdf (PBL Netherlands Environmental Assessment Agency, 2015).

74. Boden, T. A., Marland, G. \& Andres, R. J. Global, Regional, and National Fossil-Fuel $\mathrm{CO}_{2}$ Emissions http://dx.doi.org/10.3334/CDIAC/00001_V2013 (Carbon Dioxide Information Analysis Center, 2013).

75. Le Quéré, C. et al. Global Carbon Budget 2015. Earth Syst. Sci. Data 7, 349-396 (2015)

A yearly authoritative update of global anthropogenic carbon emissions, and natural and anthropogenic sinks.

76. Armstrong, J. S. \& Green, K. C. Forecasting dictionary http://www.forecasting principles.com/index.php/forecasting-dictionary [accessed 13 July 2012] (2012)

77. Nakićenović, N. \& Swart, R. IPCC Special Report on Emissions Scenarios http://www.ipcc.ch/ipccreports/sres/emission/index.php?idp=0 (Cambridge Univ. Press, 2000).

78. IEA. World Energy Outlook 2014 http://www.worldenergyoutlook.org/weo2014/ (International Energy Agency, 2014)

79. Meinshausen, M. et al. National post-2020 greenhouse gas targets and diversity-aware leadership. Nat. Clim. Change 5, 1098-1106 (2015).

80. UNFCCC. Review of the Implementation of Commitments and Other Provisions of the Convention. Report No. FCCC/CP/2002/8, http://unfccc.int/resource/docs/ cop8/08.pdf, 7 (UNFCCC, 2002).
Supplementary Information is available in the online version of the paper.

Acknowledgements We thank all involved in the UNEP Emissions Gap Report, in particular J. McGlade, J. Alcamo and B. Metz, the members of the steering committee, all its authors, and the secretariat at UNEP-DTU, in particular A. Olhoff and J. Christensen. We acknowledge and are grateful for the data contributions of, and discussion with, all the global and national modelling groups, in particular M. Rocha, B. Hare, M. Schaeffer (Climate Analytics, Germany, Climate Action Tracker), L. Jeffery (PIK, Germany, Climate Action Tracker), P. van Breevoort (Ecofys, The Netherlands, Climate Action Tracker), A. Admiraal, M. Roelfsema, H. van Soest (PBL, The Netherlands), N. Forsell (IIASA, Austria), L. Cozzi, F. Kesicke (IEA, France), J. Cranston Turner, R. Boyd (LSE, UK), S. Dockweiler (DEA, Denmark), L. Siegel, E. Sawin (Climate Interactive, USA), A. Kitous, K. Keramidas, G. Grassi (JRC, European Commission), G. Iyer (PNNL, USA), and the UNFCCC Secretariat. Without their contributions, this Perspective would have had a much more limited data basis. We thank S. Sterl (NewClimate Institute, Germany) and M. Roelfsema (PBL, The Netherlands) for assistance with data analysis, M. Strubegger (IIASA, Austria) for providing load factor estimates, V. Krey and O. Fricko (IIASA, Austria) for providing capture efficiencies for negative emissions technologies, and J. Cook for critical feedback on the manuscript and figures. We acknowledge and thank the International Institute for Applied Systems Analysis (IIASA) for hosting and maintaining the IPCC AR5 Scenario Database. J.R. and K.R. received funding from the European Union's Horizon 2020 research and innovation programme under grant agreement No. 642147 (CD-LINKS). M.M. is the recipient of an Australian Research Council (ARC) Future Fellowship (grant number FT130100809).

Author Contributions The paper was initiated during discussions between M.d.E., N.H., H.W., J.R. and other members of the UNEP Gap Emissions Gap Report author team; all authors were involved in designing the research; the quantitative INDC analysis was coordinated by M.d.E., N.H. and H.F. with substantial contributions from T.F., H.W., R.S., F.S. and M.M.; the analysis of post-2030 implications was performed by J.R., with substantial contributions from K.R.; J.R. created all figures and was responsible for the overall coordination of the paper. J.R. and N.H. led the writing of the paper, with substantial contributions from all authors.

Author Information Reprints and permissions information is available at www.nature.com/reprints. The authors declare no competing financial interests. Readers are welcome to comment on the online version of the paper. Correspondence and requests for materials should be addressed to M.d.E. (Michel.denElzen@pbl.nl) or N.H. (n.hoehne@newclimate.org). 


\section{Author Queries}

Journal: Nature

Paper: nature18307

Title: Paris Agreement climate proposals need a boost to keep warming well below $2^{\circ} \mathrm{C}$

\begin{tabular}{|l|l|}
\hline $\begin{array}{l}\text { Query } \\
\text { Reference }\end{array}$ & Query \\
\hline 1 & $\begin{array}{l}\text { AUTHOR: This PDF proof has been produced on the basis of your corrections to this preproof } \\
\text { and contains the main-text figures edited by us, but not the Supplementary Information, which } \\
\text { we do not edit at all. When you receive the PDF proof, please check that the display items are } \\
\text { as follows (doi:10.1038/nature18307): Figs 1, 2 (colour); Tables, 1, 2; Boxes, 1; Extended Data } \\
\text { display items, none; SI, yes. Please check the edits to all main-text figures and tables very care- } \\
\text { fully, and ensure that any error bars in the figures are defined in the figure legends. }\end{array}$ \\
\hline $\begin{array}{l}\text { Web } \\
\text { summary }\end{array}$ & $\begin{array}{l}\text { The objective of the Paris climate agreement is to limit global-average temperature increase } \\
\text { to well below } 2 \text { degrees Celsius above pre-industrial levels and to further pursue limiting it to } \\
1.5 \text { degrees Celsius; here, the adequacy of the national plans submitted in preparation for this } \\
\text { agreement is assessed, and it is concluded that substantial enhancement or over-delivery on } \\
\text { these plans is required to have a reasonable chance of achieving the Paris climate objective. }\end{array}$ \\
\hline
\end{tabular}

\section{SUBJECT WORDS}

Earth and environmental sciences/Climate sciences/Climate change/Climate and Earth system modelling [URI /704/106/694/1108];Earth and environmental sciences/Climate sciences/Climate change/Climate-change mitigation [URI /704/106/694/682].

\section{TECHNIQUE TERMS}

Techniques: Not Applicable.

\section{For Nature office use only:}

Layout

DOl

Title

Authors

Addresses

First para
Figures/Tables/Boxes

Error bars

Colour

Text

Methods

Received/Accepted

AOP

Extended Data
References

Supp info

Acknowledgements

Author contribs

$\mathrm{COI}$

Correspondence

Author corrx

Web summary

Accession codes link 